\title{
1. \\ PROBLEM ETIČKOG ANGAŽMANA \\ U DESNIČINIM LJESTVAMA \\ JAKOVLJEVIM
}

\section{Jadranka Brnčić}

UDK: 821.163.42-2Desnica,V.

Izvorni znanstveni članak

Sažetak: Glavni lik Desničine drame već bismo po imenu i po fizičkoj karakteristici njegove hromosti mogli dovesti u vezu s istoimenim likom biblijske drame u Knjizi Postanka. No, sam nam autor izravnim naslovom, a onda još i motom, jasno naznačuje da ta veza nije slučajna i nebitna, nego da se upravo na njoj i na njezinim skrivenim slojevima gradi tenzija njegove drame. Ovaj rad, polazeći od Barthesova tumačenja biblijske perikope, kuša osvijetliti i odgovoriti na pitanje zašto je Desnici bio predloškom upravo biblijski lik Jakova koji bješe čovjek lukav i kukavan ali kadar promijeniti se. Iako kritičari i povjesničari hrvatske književnosti smatraju dramu jednim od slabijih Desničinih umjetničkih ostvaraja, pa se stoga u svojim osvrtima i analizama rijetko pomnije zadrže na njoj, Jakovljeve ljestve u sebi sadrže sve glavne teme autorova opusa, teme koje se pletu oko esencijalnoga: moralnih dilema i katarze. Prelamanjem radnje kroza san postiže se nova prostorna i vremenska dimenzija u kojoj je moguće da se likovi uvijek iznova preispituju. Predložak je prilika za širenje asocijativnih krugova, psiholoških, etičkih, filozofskih. Kao i u biblijskoj priči. Samo je rješenje, koje ostaje otvorenim, drukčije.

Ključne riječi: biblijski Jakov, Desničin Jakov, strukturalna analiza, angažman intelektualca, etička perspektiva poetskoga

$\sqrt{5}$

ladan Desnica (1905.-1967.) u nekoliko je navrata u svojem spisateljskom radu posezao za biblijskim ili religijskim motivima, ali tek kao marginalnim, asocijativnim impulsima za svoje priče: tako u pripovijetci Spiriti (Jeremijina siročad) (1954.) ironično opisuje zazivanje duhova, pri čemu je ime 'Jeremija' parodijski suprotstavljeno biblijskom Jeremiji; u Svetom Sebastijanu (1955.) bavi se motivom ovisničke ljubavi, dok mu sveti Sebastijan služi kao likovni predložak za prikaz bolesnoga ljubavnika.

Glavni lik njegove drame Ljestve Jakovljeve (1961.) već bismo po imenu i po fizičkoj karakteristici njegove hromosti mogli dovesti u vezu $s$ istoimenim likom biblijske drame $u$ Knjizi Postanka (usp. Post 32,32). No, i sam nam autor izravno, naslovom, a onda još i motom, jasno naznačuje da ta veza nije slučajna i nebitna, nego da se upravo na njoj i na njezinim skrivenim slojevima gradi tenzija njegove drame. Pokušat ću osvijetliti i tumačiti zašto je biblijski lik čovjeka, lukava i kukavna, koji i očev i Božji blagoslov nije primio 
nego se za njega izborio te se tek onda postupno mijenjao, bio Desnici predloškom. I je li Desnica u biblijskome tekstu nalazio sadržajni okvir za svoju dramu ili je, zapravo, propitivao i štogod drugo.

\section{Dvije priče}

U biblijskim recima, koje je Desnica stavio kao moto i stanovit okvir svoje priče, dva su ključna događaja: Jakovljev san o ljestvama što stoje na zemlji a vrhom dotiču nebo $s$ anđelima koji se po njima penju i silaze (Post 28,12) te Jakovljeva noćna borba s nekim čovjekom (Post 32,24). Oba događaja bitno određuju Jakovljev lik i njegov simbolički potencijal u biblijskom tekstu. A on je nastao iz životnoga konteksta: Jakov je prvo na prijevaru dobio blagoslov namijenjen njegovu bratu prvorođencu, a potom se prilikom bijega od bratove osvete, kroz okolnosti koje su mu, unatoč svemu, pokazivale da je od Boga izabran da bude baštinikom njegova obećanja - mijenjao, tj. otvarao za transcendentno, što Immanuel Kant definira kao ono što uvjetuje spoznavanje, što je apriornoga podrijetla i što uopće omogućuje iskustvo. No, i tu je Jakov prvo Bogu htio nametnuti svoje uvjete sve dok, paradoksalno poražen vlastitom pobjedom, nije prihvatio nesavladivu Božju volju, što ga je, naposljetku, preobrazilo iz prepredena i kukavna u jaka i ponizna čovjeka.

U Desničinoj drami Jakov (Pećina) nenadano se našao u zbrci ratnih događanja (Drugi svjetski rat) te i dalje ustrajao na svojem intelektualističkom stavu da se ne vrijedi miješati nego nadmoćno ostati sâm, po strani, „između jučer i sutra”, u „onoj tananoj granici između snoviđenja i jave gdje se nalaze predah i zaborav”, a koji sam opisuje kao „otvaranje nebesa, pružanje ljestava od neba do zemlje i uzlaženje i silaženje anđela". ${ }^{1}$ On negira transcendentno kao mogućnost da se čovjeku obrati ono sasvim Drugo što ga nadilazi, aludirajući, čini se, na Freudovo tumačenje smrti Boga kao na svojevrsno ocoubojstvo. ${ }^{2}$ No, događaji su ga uskoro počeli svladavati: prvo mu je prijatelj spočitnuo da ništa nije učinio za ženu koju je volio, Veru, Židovku odvedenu u logor; potom, nakon bombaškoga napada grupe mladih, među kojima je i prijateljeva kćerka Dunja, Nijemci hvataju taoce i spremaju odmazdu; poznanik Majer, njuškalo koje radi za Nijemce, spomene mu uzgredno da bi mogao posjetiti bivšega školskog kolegu Jozefa Hubera, danas Sturmführer i založiti se za svoje. U drugom činu drame Pećina posjećuje Hubera u njegovu štabu te dok ga čeka, uzrujan i iscrpljen - zaspi. U snu proživi cijeli susret. Prepreden i obrazovan, Huber navede Jakova, na kraju, umjesto da se raspita o Veri te založi za Dunju i njezine drugove, da ih zapravo izda. Shvativši užas svojega čina, nudi svoj život u zamjenu za uhićene mlade ljude, ali biva ismijan te, naposljetku, počini samoubojstvo. Ali njegovu smrt mladi ne shvaćaju ni kao pokajanje ni kao žrtvu: „kad je bezvrijedan jedan život, bezvrijedna je i žrtva tog života”. ${ }^{3}$ Kada se probudi, odluka je tek pred njim.

Biblijsku priču, dakle, zanima veza s transcendentnim, $s$ vertikalnom dimenzijom ljudskoga bića, dok je Desnica zaokupljen horizontalnim - psihološkim, intelektualnim i etičkim

\footnotetext{
Vladan DESNICA, Ljestve Jakovljeve, Zagreb 1977., 27.

Isto, 45 .

Isto, 79 .
} 
prostorom unutar kojega se kreće čovjek i u kojem intelektualac, suočen s aporijama društva, ostaje politički i društveno neopredijeljen, misleći da će na taj način zadržati neutralnost i tzv. objektivnost.

\section{Strukturalna analiza}

Na sadržajnoj razini dviju priča, dakle, nalazimo jedva što zajedničkog - one se na neki način mimoilaze. Međutim, ono što povezuje biblijsku i Desničinu priču nije tema nego ponajprije: naratološki postupak. Obje su priče sastavljene od gotovo istih naratoloških elemenata, samo su oni u svakoj drukčije poredani te samim tim zadobivaju drukčija značenja.

Strukturalna analiza teksta, prema Barthesu, ${ }^{4}$ ima tri zadataka: 1 . klasifikaciju psiholoških i društvenih atributa likova umiješanih u narativni tijek događanja (indicijalna, tj. sadržajna analiza); 2. klasifikaciju funkcija likova, tj. onoga što oni rade shodno svome narativnom statusu: Pošiljalac, Potražitelj, Glasnik itd. (aktancijalna analiza) i 3. klasifikaciju radnji likova u njihovu narativnome sklopu pri čemu su narativne radnje organizirane u sekvencije, tj. u nizove uređene prema pseudo-logičnoj shemi (sekvencijalna analiza).

Dva lika, biblijski Jakov i Desničin Jakov, dakle, na razini indicijalne analize jedva da imaju čega zajedničkog. Doduše, obojica osobne interese stavljaju na prvo mjesto i pritom bivaju sami, no biblijski se Jakov izravno suočava sa svojim dilemama te se s vremenom pokazuje jakim dok se Pećina izbjegava izravno suočiti sa samim sobom. Naposljetku se pokazuje slabićem i kukavicom.

Greimasov aktancijalni model ${ }^{5}$ dijeli likove u šest formalnih skupina aktanata, i to prema onome što rade s obzirom na svoj status u priči. U biblijskoj priči Jakov je i subjekt (onaj koji zahtijeva kretanje) i objekt (onaj zbog kojeg se to kretanje događa). On je Pošiljalac poruke kretanja i njezin Primalac, a ujedno je, vlastitom snagom, i Pomagač. Protivnik je ovdje sam Bog i u slici gaza i u liku „nekog čovjeka”, ili anđela, kako se obično tumači (on je onaj koji osujećuje kretanje). U Desničinoj drami Jakov je, čini se, samo objekt (kretanja izazvana nesvjesnim u snu); on je i (nesvjestan) Pošiljalac, i Primalac, i Protivnik. Pomagača, čini se, nema ili ga Jakov ne sluša. Likovi (Jakov, anđeli i Bog) koji pokreću radnju u biblijskoj priči u Desničinoj priči smješteni su unutar jednog jedinog lika - u Jakovu. Biblijska priča ima strukturu bajke, ${ }^{6}$ a Desničina dramsku. Samim premještanjem naratoloških elemenata, tj. sekvenci (u objema pričama identičnih) iz jedne strukture u drugu, događaju se i pomaci funkcija likova (koji inače imaju istu semantičku popudbinu) - u drukčije poredanim (ili reduciranim) sekvencama i njihove funkcije u diskursu postaju različite, što, zapravo, i tvori razliku i među žanrovima. Slično „preslagivanje” elemenata može se uočiti i u transpoziciji biblijske priče o Jobu, također bajkovite strukture, u roman F. M. Dostojevskoga Braća Karamazovi: glasovi biblijske priče, čiji su nosioci Bog, Sotona i Job, u romanu se javljaju unutar jednoga lika - Ivana te pridonose složenosti romaneskne strukture na drukčiji način nego je to moguće u bajci: dijalozi među likovima transponiraju

\footnotetext{
Usp. Roland BARTHES, „Borba s anđelom - tekstualna analiza Postanka 32,23-33”, Književna smotra, 26/1994., br. 92-94, 79.-83.

Isto, 82.

6 Bajke u Proppovom smislu te riječi: u njima funkcije predstavljaju segmente radnje. Usp. R. BARTHES, „Borba s anđelom", 82.
} 
se u višeglasje unutrašnjeg monologa jednoga jedinog lika. ${ }^{7}$ Glasovi biblijske priče i u Desničinu Jakovu kao da postaju njegovim vlastitim glasovima koji se spore u njemu samom.

Biblijski tekst može se načelno podijeliti u tri sekvence: 1 . prelazak, 2. borba i 3. imenovanje. Patrijarh Jakov, u snu o anđelima posredno iniciran u događaj koji slijedi, odlučuje prijeći rijeku Jabok, pobrine se da njegova obitelj i imovina prijeđu prvi te, ostavši sam, susreće neznanca s kojim započne borbu. Budući da se u borbi pokazao jakim, dobiva novo ime - Izrael, koje izražava tu jakost. Desničin Jakov prolazi prve dvije sekvence. $\mathrm{Na}$ prelazak se, međutim, nije sam odlučio nego ga je izazov, potaknut vanjskim događajima, podsvjesno mučio, pa ga je on odsanjao. No, budući da se unaprijed osjećao poraženim, prelazak mu se u snu dogodio u izvrnutu smislu, kao negativan: Jakov nije prešao iz jednoga stava u drugi, iz neopredijeljenosti u angažiranost, nego je ostao zatečen spoznajom o tome koja je krajnja izvedenica njegova prvotna stava. Stoga nije dobio novo ime. Stoga mu Desnica nije dopustio katarzu, iskupljenje, a možda ni kasniju promjenu. Konačni ishod njegove borbe, zapravo, ostaje neizvjestan. A za samu intenciju priče nije ni bitan.

Za razliku od biblijskoga pisca koji svoju naraciju vodi etiološkim, tj. deduktivnim putom - poznate posljedice (hramanje i novo ime) tumači naknadno: hramanje je znamenje, a ime je sinonim za unutarnju preobrazbu, Desnica ide induktivnim putom - Pećina (prezime koje može asocirati na jakost koje nema ${ }^{8}$ ) postupno biva zatečen posljedicama svojega stava i ne može ih (još) protumačiti: njegovo hramanje nema veze $s$ događajem (osim što svjedoči da je jednom, u Galiciji, ipak sudjelovao u ratu), a ime, zapravo, gubi. Biblijski Jakov ranjen je u bedro, tj. iščašen mu je kuk, što je posljedica i simbol dubokoga zahvata u njegovo biće, dok je Desničin Jakov ranjen u koljeno, što se može shvatiti znakom njegove nemogućnosti da poklekne, savije koljeno. Suočavanje s Bogom ili samim sobom, čini se, ne događa se bez gubitka na jednoj razini da bi se dobilo na drugoj. Biblijski Jakov spreman je i na pobjedu i na gubitak, dok Desničin Pećina nije spreman ni na jedno ni na drugo.

\section{San i nesvjesno}

Dva su ključna leitmotiva obiju priča: san i borba. U biblijskoj priči san priprema za borbu, u Desničinoj san je artikulira. Zato biblijski Jakov iz iskustva koje mu je priskrbio san ulazi u novo iskustvo - borbu s „nekim čovjekom”, dok su u Desničinu Jakovu ta dva iskustva jedno te isto: njegov san jest ujedno i borba, zato košmar. U slučaju biblijskoga sna riječ je o snu koji uvodi u transcendentalno iskustvo, dok Jakovu Pećini san prevodi stanje njegove podsvijesti. Biblijski Jakov ne sanja ljude, nego anđele. S jednim se i bori. Jakov Pećina sanja ljude koji mu u snu kažu ono što je on sam na javi začeo svojim stavovima.

Usp. Jadranka BRNČIĆ, „Job u Braći Karamazovima”, O kraljevstvu nebeskom - novo i staro. Zbornik radova u čast Bonaventuri Dudi, (ur. Mario Cifrak), Zagreb 2001., 499.-507.

8 No, „pećina” u hrvatskome jeziku ne znači samo stijenu, nego i spilju - veliku šupljinu u stijeni; u prenesenom smislu: jazbinu, sklonište sumnjivih ljudi. (Usp. Vladimir ANIĆ, Rječnik hrvatskog jezika, Zagreb 1998.3) U povijesti filozofije pećina, tj. spilja pojavljuje se već kod Platona: u njoj su ljudi leđima okrenuti svjetlu pa vide samo sjene i tumače ih kao stvarnost. Francis BACON u Novom Organonu govori o idolima spilje kao idolima pojedinog čovjeka: svatko, osim zabluda ljudske prirode uopće, ima svoju posebnu spilju koja lomi i kvari svjetlo prirode. Tako, kaže Bacon, zbog različitosti dojmova javljaju se u duši opterećenoj pristranošću i predrasudama i različite spoznaje. Jakov Pećina je „zatvoren u spilju građanskoga narcisoidnog individualizma”. (Usp. Dušan MARINKOVIĆ, Iz tijesna vremena, Zagreb 2001., 144.) 
Zapravo, sanja samoga sebe. Činjenica da oba lika sanjaju ponovno nam gotovo ništa ne kazuje o tome što je biblijskom i dramskom tekstu zajedničko na sadržajnoj razini, ali zato odaje da je i u jednom i u drugom tekstu san - naratološki motivacijski postupak.

Kadgod se u biblijskim tekstovima, ili uopće u književnoj prozi, uvodi san, najčešće prethodi važnom događaju, a naratološka mu je funkcija uvođenje u taj događaj bez tumačenja. U snu se zamršuju i razmrsuju naratološki čvorovi, a da ih ne treba motivirati ni tumačiti. Oni pripadaju svijetu nesvjesnoga, a logika nesvjesnoga je metonimijska logika.

U biblijskoj priči, strukturno, pokretač je - buđenje (buđenjem se pokreće i Jakov i sam diskurs, a na čitatelju je da iščita značenje toga kretanja); u Desničinoj pak priči, strukturno pokretač je - sam san (zato diskurs, na kraju, kada Jakovljeva pasivnost pokrene nesvjesne silnice, zastaje eda bi čitatelj iščitao značenje vlastitoga kretanja).

Prvi čin Desničine drame zapravo je uvod u drugi. Prvi čin je antitetički koncipiran dijalog između Pećine i njegova prijatelja Orljaka, Dunjina oca, pri čemu Orljak zastupa načelo bezuvjetnog opredjeljenja i aktivnog otpora u ratu, dok Pećina brani pravo na osobnu slobodu od opredjeljivanja i zastupa, zapravo, malograđanski i sebičan status quo. Drugi čin drame teorijski dvoboj iz prvog čina konkretizira u - snu. Pećinin san sav je svojevrsna projekcija nesvjesnoga: Jakov je u njemu onakav kakav bi mogao biti kada bi ga na to navele okolnosti. ${ }^{9}$ Jedan od motiva pokretanja unutrašnjeg mehanizma u kojem Jakovljevo Ja konačno dolazi u odnos s drugim Ti jest svakako njegova veza s Verom. U snu ona se ne pojavljuje ni kao logorašica ni kao Jakovljeva krvnica, nego kao - Huberova ljubavnica, što zapravo i ne čudi previše budući da se Huber u istome snu pokazuje u mnogočemu kao Jakovljev dvojnik, tj. kao on sam gurnut do krajnjih granica odjelotvorenja vlastitih stavova. Za Desničinu tehniku oblikovanja likova karakteristično je to da se isti nazori raspoređuju na različite, a različiti nazori na iste likove pa to završava potkopavanjem njihovoga misaonog integriteta. ${ }^{10} \mathrm{U}$ tom smislu je i Vera u snu izvrnuta stvarna Vera. Naime, grižnja savjesti, zbog propuštanja pomoći i solidarnosti s prijateljicom odvedenom u logor, pritišće Jakova i on mora naći alibi (ne opravdanje, jer bi pravdati se značilo priznati krivicu) za svoj postupak. Ali, u snu taj se alibi zaodijeva u groteskno ruho: Židovka postaje ljubavnicom njemačkoga šefa policije. Ona je, dakle, i sama izdajnik pa u tom svjetlu Jakovljeva izdaja ne izgleda tako strašnom. Ipak, činjenica da se Jakovljeva izdaja dogodila samo u snu ima za njega gotovo katarzičan učinak. Ali ne posve. I ne zadugo.

Predložak sna je u Desnice prilika za širenje asocijativnih krugova, psiholoških, etičkih, filozofskih. „Prelamanjem radnje kroz san postiže se nova prostorna i vremenska dimenzija u kojoj je moguće da se likovi uvijek iznova preispituju”. ${ }^{11}$ Da je naratološki tijek u Desničinoj drami vođen linearnom logikom, tj. da je Jakov naprosto postao izdajicom ili, pak, shvatio koje su krajnje konzekvence njegovih stavova te se promijenio, ne bi bilo moguće iz teksta drame iščitavati tolike slojeve značenja. U vremenskom i logičnom

Usp. Predrag PROTIĆ, „Zabeleške uz čitanje jedne drame. Marginalija uz 'Ljestve Jakovljeve’ Vladana Desnice”, Zadarska revija, 17/1968., br. 1, 67.

10 Usp. Vladimir BITI, Doba svjedočenja: tvorba identiteta u suvremenoj hrvatskoj prozi, Zagreb 2005., 160.

11 Dušan RAPO, Književni rad Vladana Desnice, disertacija, Filozofski fakultet, Zagreb 1984., 402. Poput Desničina romana Proljeća Ivana Galeba (1957.) te većine njegovih proznih djela i Ljestve Jakovljeve dio su „epistemološkog projekta" kasnog ili visokog modernizma u kojem se naziru i naznake nastupajućega postmodernističkog skepticizma i stalnoga samopreispitivanja. (Usp. Milivoj SOLAR, „Tehnika uvođenja eseja u roman Proljeća Ivana Galeba”, 36.) 


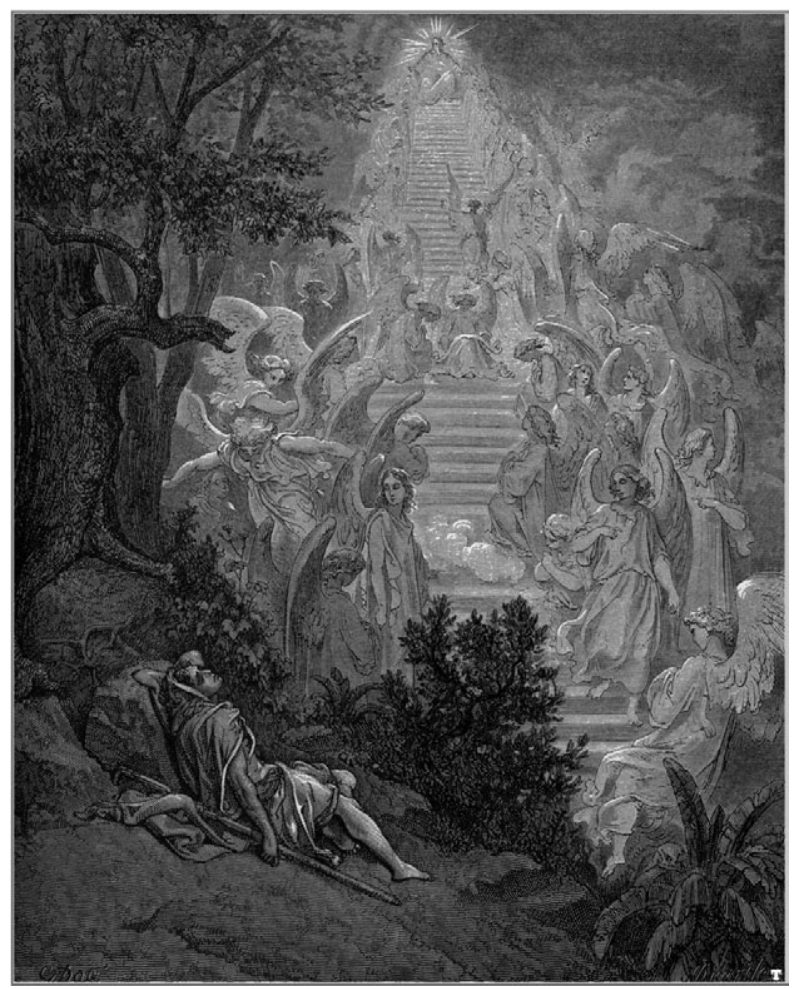

Slika 1. Gustave Doré (1832.-1883.), Jakovljev san

pogledu u snu je riječ o mehanizmu pomicanja: nešto što je logički prethodilo doživljava se (ili postaje, upisuje se u strukturu) kao kasnije iskrivljavanje neke navodno „izvorne” priče. Elementarna matrica „rada sna" podrazumijeva razlikovanje između latentnog sna-misli i nesvjesne želje koja se artikulira u snu: u radu sna latentna misao je šifrirana, pomaknuta misao, ali upravo se samim tim pomicanjem artikulira druga nesvjesna misao. ${ }^{12}$ Činjenica da je Jakov sanjao jednu od mogućnosti, dopušta da sva pitanja ostanu otvorenima. Jakov ostaje u „neodlučivu i tjeskobnu međuprostoru odjelotvorivanja i proradbe, bliskosti i udaljenosti, empatije i ironije - u neodređenu stanju identifikacijskog potraživanja”. ${ }^{13}$

\section{Problem uprizorenja}

Kritika je prigovarala da su Ljestve Jakovljeve prvenstveno drama za čitanje, a ne za prikazivanje. ${ }^{14}$ To, uostalom nije strano ni Desničinu poimanju teatra i odnosa tekst-predstava: Ivan Galeb u Desničinu romanu Proljeća Ivana Galeba raspravlja s jednim glumcem o dramskoj poeziji te tvrdi da „istinska velika djela dramske poezije ne bi trebalo prikazivati jer njihov 'goli tekst' ne treba nikakve integracije ili nadopune; ta su djela i bez 'scenske realizacije' potpuno dorečena, u sebi cjelokupna, sama sebi dovoljna, dokraja dorečena". ${ }^{15}$

Scenski život drame bio je kratak i neuspješan. ${ }^{16}$ Izvedena je 1961. u Jugoslovenskom dramskom pozorištu u Beogradu, u režiji Nikole Tanhofera, ali se na repertoaru nije zadržala ni cijelu sezonu. Drama je bila stavljena i na repertoar kazališta u Zadru, ali iz „nepoznatih razloga"17 do izvedbe nikad nije došlo.

12 Usp. Slavoj ŽIŽEK, O vjerovanju, Zagreb 2005., 12.-13.

13 V. BITI, Doba svjedočenja, 168.

14 Usp. P. PROTIĆ, „Zabeleške uz čitanje jedne drame”, 70. Nedavno je (14. 7. 2011.) Dramski program Trećega programa hrvatskog radija emitirao dramu u režiji Dejana Šorka.

15 Vladan DESNICA, Proljeća Ivana Galeba, Sabrana djela, knj. II, Zagreb 1975., 215.; usp. Krešimir NEMEC, Vladan Desnica, Zagreb 1988., 114.

16 Dragoslav GRBIĆ, „Praizvedba 'Ljestava Jakovljevih' Vladana Desnice”, Telegram (Zagreb), br. 44, 24. 2. 1961., 4.; Marija GRGIČEVIĆ, „Osrednje predstave: VI Jugoslovenske pozorišne igre”, Večernji list (Zagreb), br. 584, 26. 5. 1961., 5.

17 Usp. o tome Vladan DESNICA, Eseji, kritike, pogledi, Zagreb 1975., 206.-207. 
Jedan od ključnih scenografskih problema pred koje Ljestve Jakovljeve stavljaju režisera i scenografa zasigurno je uprizorenje Jakovljeva sna. I biblijska i Desničina priča unutarnji dijalog čovjeka stavljena pred stanovite izazove izražavaju utjelovljujući njegove glasove u drugim likovima. Međutim, biblijska priča ima strukturu i logiku bajke ${ }^{18}$ pa za njezino uprizorenje prvo rješenje jest - uprizoriti je kao bajku. Sekvence se tad nižu kulturološkom $\mathrm{i}$ iskustvenom logikom: san, prelazak, borba, nastavak kretanja. S Desničinom dramom problem je kompleksniji. Kao što je spomenuto: kretanja zapravo nema, a san i borba spojeni su u jednu sekvencu. Ako se prikaže kao snoviđenje, makar i košmarno, gubi svoju gorčinu i jetku ironiju. Ako li se, pak, prikaže „realistički”, gubi auru nesvjesnoga te intenzitet znaka i pitanja.

\section{Dva početka i dva kraja}

Podsekvenca prelaženja iz mirovanja u akciju u biblijskoj je priči u stanju zalihosti: informacija je dana i ponovljena, što je uobičajeno za biblijski diskurs jer jamči objedinjavanje, tumačenje i osiguravanje poruke. No, u današnjeg čitatelja takva zalihost izaziva stanovito trenje u razumijevanju teksta. Naime, čini se kao da je Jakov dva puta prešao gaz: jednom je ustao, okupio svoju obitelj te prešao na drugu obalu rijeke (Post 32,23), a drugi put je okupio obitelj, poslao ih na drugu stranu te ostao sam (Post 32,24). Moguće je da je biblijski pisac, kao što se to često događa u redakciji biblijskoga teksta, naprosto spojio dvije usmene predaje o tom događaju. No, takav spoj nije samo slučajan - on spaja i dva različita čitanja teksta: folklorno čitanje $s$ mitskom referencijom ispitivanja nečije snage (koje završava tumačenjem etimologije toponima Penuel - hebr. peniel: „lice Božje”) i religiozno čitanje u kojem svaka sekvenca postaje znamenje ${ }^{19}$ (a koje završava tumačenjem duhovnoga značenja imena Izrael - hebr. Israel: „onaj tko se borio s Elohimom, tj. Bogom”). Biblijska priča, dakle, ima dva početka.

Desničina, pak, priča ima dva završetka, tj. autor je napisao dvije verzije završetka. U prvom izdanju drame (Savremenik, Beograd 1961.) Jakov je, tek što se bio probudio i pomislio s olakšanjem kako je sve to bio samo san, doživio da su Dunju i njezine drugove ipak uhitili te da ih upravo privode Huberu, čime je ponovno stavljen u situaciju iz sna te i sam kaže: „Strahota!... Sad čitava priča započinje iznova!” No, glasovi iz sna nastavljaju mu govoriti o (bez)vrijednosti njegove smrti. I on je na kraju prihvaća: „Ako smo jednom u sebi dokraja doživjeli iskustvo smrti, život prestane da bude nešto iznad svih dilema i svih vrednota...!", ustaje i, unatoč obavijesti da ga Huber neće primiti jer da je zauzet, čvrst, odlučuje da ga mora primiti jer - „u toj važnoj stvari i on ima svoju riječ”. ${ }^{20}$

U kasnijim izdanjima Desnica je posljednje replike izbacio. Jakov se ne uspravlja i ne kaže ništa, već ostaje poput zgužvane figure na klupi. ${ }^{21}$ Time čitatelja lišava znamenja i nade. Stoga, čini se, izbor ne ostavlja Jakovu, nego ga prepušta čitatelju.

\footnotetext{
Usp. R. BARTHES, „Borba s anđelom - tekstualna analiza Postanka 32,23-33”, 82.

19 Isto, 80.

20 V. DESNICA, Ljestve Jakovljeve, 83.

21 Vladan DESNICA, „Ljestve Jakovljeve”, Sabrana djela, knj. I, (red. Slavko Korać), Zagreb 1974., 333.
} 


\section{Biti angažiran}

U Ljestvama Jakovljevim ljudska je autarkičnost podvrgnuta žestokoj kritici. Drama počiva na svojevrsnoj moralnoj kazuistici: konformistički kompromis, neangažiranje u presudnom trenutku, neodgovornost prema bližnjima i davanje prednosti osobnim interesima - sve to završava moralnom katastrofom. Djelovati ili ne, uvjetovanost i ograničenost ljudske spoznaje, i iz toga nemogućnost ispravne prosudbe o potrebi, svrsi i smislu djelovanja - teme su koje se neprestano pojavljuju u Desničinim djelima. Njegov se Jakov možda može razumijevati i kao žrtva nemogućnosti razborite odluke, žrtva svijesti o aporetičnosti razmišljanja o ispravnosti djelovanja. U krug takva razmišljanja ulazi i ono o odnosu pravde i pravednosti. Pravednost traži hitno i neodgodivo djelovanje, pa i po cijenu neizvjesnosti spoznaje, dok se pitanja o zakonitosti i ispravnosti zakona te teoretiziranje oko toga problema najčešće vrte u krug.

Prividna intelektualistička nadmoć Jakova Pećine, njegovi sterilni, ekskluzivni stavovi o tome kako se valja ponašati u iznimnim situacijama kao što je rat ili vladavina totalitarističkoga režima, vode naprosto - u izdaju. Kao potencijalan spasilac, Jakov Pećina se premeće u izdajicu, „užasnut pred spoznajom da je njegova slika i tumačenje svijeta i života čista fikcija, ali fikcija opasna, jer svojim kompromisom sa zlom" potiče zlo. ${ }^{22}$ I neopredijeljenost je, naposljetku, opredijeljenost, a odgovornost se naprosto ne može izbjeći. Pred patnjama drugih „nutarnja emigracija” naprosto prestaje vrijediti.

Pitanje o angažmanu intelektualaca, kao ponajprije filozofsko, a onda i etičko pitanje osobito je bilo aktualno nakon Drugoga svjetskog rata. Rječnik Le Nouveau Petit Robert (Dictionnaires Le Robert, Pariz 1993.) intelektualni angažman definira kao „stav intelektualca, svjesna svoje pripadnosti društvu i vremenu, koji se odriče pozicije promatrača te svoju misao i rad stavlja u službu nekoj općoj svrsi”. Jean-Paul Sartre ljudsku slobodu shvaća kao odgovornost: angažira li se ili ne, čovjek je odgovoran. ${ }^{23}$ Razrada te misli može se pratiti preko fenomenologa sve do Emmanuela Levinasa koji etiku shvaća kao „prvotnu filozofiju”, a subjekt tek u njegovu odnosu prema Drugome. Po Levinasu mi smo neprestano u stanju odgovornosti, a da to ni ne želimo ni ne tražimo - poziv Drugoga prethodi svakom dogovoru i predusreće svaku slobodu. „Svi smo pred svima odgovorni za sve i sva” izreka je Dostojevskoga koju Levinas rado citira. ${ }^{24}$ Međutim, kako je moguće odgovoriti „Evo me!” ako subjekt ne preuzima inicijativu? Etika nije ukorijenjena u ontologiji supstance, ali jest itekako u ontologiji. Osvjedočenje sebstva da jest kroz djelovanje jedini je način da se sebstvo odražava kao sebstvo kroz aporije vlastite i tuđe drugosti, pa i drugosti Božje. ${ }^{25}$ Smjer od drugoga prema sebstvu strukturira epistemološku svijest o drugomu, a smjer od drugoga prema sebstvu etičku odgovornost kao odaziv na poziv drugoga. Epistemološki i etički aspekt ne idu jedan bez drugoga.

\footnotetext{
Usp. D. MARINKOVIĆ, Iz tijesna vremena, 145.

Jean-Paul SARTRE, L'existentialisme est un humanisme, Paris 1946., 146.

Usp. Agata ZIELINSKI, Levinas - la responsabilité est sans pourquoi, Paris 2004., 123.

25 Drugost Božja tema je ontoteologije i misticizma te bi ju se dalo pratiti od Anselma (njegova nastojanja da drugost Božju učini inteligibilnom), Meistera Eckharta (njegove kontemplacije o Bogu u ne-bitku Stvaranja) i Nikole Kuzanskoga (njegova promišljanja o slučajnosti, negaciji i ne-drugosti kao toposima Božje drugosti), preko Luthera (njegova insistiranja na drugosti Božjoj), Heideggera (njegova promišljanja drugosti mišljenja bitka koje se može nazvati teologijom razlike) pa sve do Derride (shvaćanja drugosti Božje kao hiperbole différance). Zanimljiv zbornik o toj temi: The Otherness of God, (ur. Orrin F. Summerell), Charlottesville - London 1998.
} 
Problem biblijskog Jakova stoga jest jednako tako problem angažmana, premda angažmana druge naravi: on kao da prvo ne može prihvatiti Božji angažman u svojem životu, a onda, nakon opetovanih iskustava Božjeg zahvata u njegov život, to čini. Iz problema sukoba dviju volja izlazi drukčije od Jakova Pećine: prvome Jakovljeve ljestve su Bog, a drugome on sam; prvi Jakov shvaća, kroz borbu zadobiva Božji blagoslov, iskače iz svoje ljudske logike i ide dalje; drugi Jakov kao da ostaje sa svojom dilemom, ne može iskočiti iz svoje logike jer se boji da bi je time poništio, a vjerojatno i sebe zajedno s njom. Ljestve, kojima se čovjek i uspinje i silazi, izazivaju kako strah i tjeskobu, tako i radost i osjećaj sigurnosti, što je dijalektika uspravnosti: uspon je interiorizacija, tj. sabiranje etičkoga, egzistencijalnoga i emotivnoga, a silazak eksteriorizacija, tj. rasipanje u vanjskom svijetu, u pukom umovanju i teoretiziranju. Jedan se Jakov uspinje, a drugi silazi; jednomu se ono božansko „spušta”, od drugoga „odlazi”.

\section{Etička perspektiva poetskoga}

Obično se drži da književno pripovijedanje, na razini narativne konfiguracije u doslovnom smislu te riječi, gubi svoja etička određenja u prilog posve estetskim određenjima. No, to reći značilo bi ne poznavati samu estetiku. Užitak koji osjećamo slijedeći sudbinu likova uključuje, doduše, napuštanje realnoga moralnog prosuđivanja, ali, u irealnom prostoru fikcije iskustva mišljenja uvode nas u veliki imaginarni laboratorij: u svojevrsno istraživanje kraljevstva dobra i zla. Nadvrednovati, tj. prevrednovati još uvijek znači vrednovati. Moralni sud nije dokinut, prije je i on sam podvrgnut imaginativnim varijacijama vlastitima fikciji.

Tekst problematizira subjekt koji ga interpretira: subjektivitet čitatelja kakav se uspostavlja čitanjem otvara prema imaginativnim varijacijama, a imaginacija pripravlja čitatelja za nove mogućnosti djelovanja. Poetski se tekst ne zaustavlja tek na tome da "ponovno opiše stvarnost" (teorijska funkcija), nego ponovno stvara svijet djelovanja (praktička funkcija). Djelovanje je slično tekstu po tome što se i jedan i drugi eksterioriziraju u tragove, postaju autonomnima, neovisnima o svojem autoru (ili agentu). U trenutku, pak, kada se posredstvom imaginacije prelazi iz diskursa u čin, otvara se etički horizont teksta. Poetika i etika u tijesnoj su vezi. Promjena svijeta - upravo to je etička perspektiva poetskoga. Stoga Desničin etički angažman i nije sudjelovanje u političkom diskursu, nego - pisanje.

Vladan Desnica sâm rijetko se oglašavao na teme intelektualca, intelektualnog angažmana, intelektualne kulture općenito. Mnogo je toga s njima u vezi njemu, umjetniku, bilo - najsuzdržanije rečeno - zazorno. Poznato je da se zalagao, pored ostalog, za legaliziranje koncepta „primijenjene književnosti” u strahu pred bilo kakvom ideologijski konotiranom literarnom estetikom. Bio je „elitist” u svojoj profesiji. ${ }^{26}$

Etička perspektiva poetskog mnogo je dalekosežnija nego se to na prvi pogled može činiti. Od odgovornog pripovijedanja i čitanja u kakvom uspostavljamo jedinstvo sa sobom do odgovornog djelovanja vrlo je malen korak - u svemu ista odgovornost prema vlastitom

Drago ROKSANDIĆ, „Vladan Desnica i Desničini susreti: razmišljanja povodom 25. obljetnice Desničinih susreta", Dijalog s povodom 5. Vladan Desnica i Desničini susreti: pogled unatrag, pogled unaprijed, (ur. Drago Roksandić i Ivana Cvijović Javorina), Zagreb 2013., 102. 
sebstvu i vlastitoj drugosti. O etici kao vjernosti samom sebi pisala je već Hannah Arendt: „Moralno ponašanje ovisi prije svega o odnosu čovjeka prema samom sebi”; ${ }^{27}$ „Ukoliko ste u raskoraku sa samim sobom, to je kao da ste prisiljeni svakodnevno živjeti sa svojim neprijateljem. (...) Kada počinite zločin, živite sa zločincem”, ${ }^{28}$ „Neke stvari ne mogu uraditi jer da ih uradim neću više moći živjeti sa samom sobom". ${ }^{29}$

Po Desnici intelektualac je naprosto etički odgovoran za sudjelovanje u zbilji. Stoga kaže:

Stvar uvijek počinje odatle: čovjeku se čini da ima da saopći nešto što je vrijedno tog truda. Često to poprima intenzitet jednog imperativa. Ponekad vid jedne etičke dužnosti. Otkriti i formulirati neke istine o čovjeku i oko njega, i time, u konačnoj liniji, od svoje strane nešto doprinijeti vječitom cilju: očovječenju čovjeka - u tome je krajnja svrha i dublji smisao svake književne djelatnosti. ${ }^{30}$

Desničin Jakov je pred izazovom očovječenja i ono se, ukoliko angažirano čita Desničin tekst, ozbiljuje u - čitatelju.

\section{$\cos$}

\section{The PROBlem of ethicAl ENGAGEMENT in DesniCA'S LJESTVE JAKOVLJEVE (JACOB'S LADDER)}

The very name of the protagonist of Desnica's play and his physical handicap (lameness) bring to mind the biblical character from the Book of Genesis and the author underlines the deliberateness of that connection by the title and the motto of the play. Moreover, this connection and its hidden layer constitute the source of the dramatic tension in the play. Drawing on Barthes' interpretation of the biblical pericope, the paper attempts to answer the question of why Desnica based his character on the biblical Jacob, a shrewd and pathetic man, yet capable of change. Although critics and Croatian literary historians consider the drama one of Desnica's weaker works and thus rarely devote much attention to it in their reviews and analyses, the play contains all major themes typical of Desnica's oeuvre, namely: moral dilemmas and catharsis. Using a dream sequence to refract the plot adds a new spatial and temporal dimension in which characters can perpetually question themselves. The template provides an opportunity to spread associative circles, psychological, ethical and philosophical, just like it is in the biblical story. Only the solution, which remains open, is different.

Keywords: the biblical Jacob, Desnica's Jacob, structural analysis, intellectual engagement, the ethical perspective of the poetic

\section{$\cos$}

\footnotetext{
Hannah ARENDT, O zlu. Predavanje o nekim pitanjima moralne filozofje, Zagreb 2006., 27.

Isto, 55 .

Isto, 63 .

30 Vladan DESNICA, „Doprinijeti vječitom cilju: očovječenju čovjeka”, Vladan DESNICA, Hotimično iskustvo: diskurzivna proza Vladana Desnice. Knjiga druga, (prir. Dušan Marinković), Zagreb 2006., 96.
} 


\section{Literatura}

Vladimir ANIĆ, Rječnik hrvatskog jezika, Zagreb $1998 .^{3}$

Hannah ARENDT, O zlu. Predavanje o nekim pitanjima moralne filozofije, Zagreb 2006.

Francis BACON, Novi Organon, Zagreb 1986.

Roland BARTHES, „La lutte avec l'ange: Analyse textuelle de Genèse 32.23-33”, Analyse Structurale et exégèse biblique, (ur. François Bovon), Neuchâtel 1971., 26.-39. (prijevod s engleskog /"The Struggle with the Angel: Textual Analysis of Genesis 32; 22-32", Image Music, Text, London 1984./: „Borba s anđelom - tekstualna analiza Postanka 32,23-33”, Književna smotra, 26/1994., br. 92-94, 79.-83.

Vladimir BITI, „Mama-Yumba i Mumbo Jumbo”, Doba svjedočenja: tvorba identiteta u suvremenoj hrvatskoj prozi, Zagreb 2005., 135.-171.

Jadranka BRNČIĆ, „Job u Braći Karamazovima”, O kraljevstvu nebeskom - novo i staro. Zbornik radova u čast Bonaventuri Dudi, (ur. Mario Cifrak), Zagreb 2001., 499.-507.

Vladan DESNICA, „Doprinijeti vječitom cilju: očovječenju čovjeka”, Vladan DESNICA, $H o-$ timično iskustvo: diskurzivna proza Vladana Desnice. Knjiga druga, (prir. Dušan Marinković), Zagreb 2006., 96.

Vladan DESNICA, Eseji, kritike, pogledi, Sabrana djela, knj. IV, (red. Slavko Korać), Zagreb 1975.

Vladan DESNICA, „Ljestve Jakovljeve”, Sabrana djela, knj. I, (red. Slavko Korać), Zagreb 1974., 267.-333.

Vladan DESNICA, Ljestve Jakovljeve, (ur. Đuro Puhovski), Zagreb 1977.

Vladan DESNICA, Proljeća Ivana Galeba, Sabrana djela, knj. II, Zagreb 1975.

Dragoslav GRBIĆ, „Praizvedba 'Ljestava Jakovljevih’ Vladana Desnice”, Telegram (Zagreb), br. 44, 24. 2. 1961., 4.

Marija GRGIČEVIĆ, „Osrednje predstave: VI Jugoslovenske pozorišne igre”, Večernji list (Zagreb), br. 584, 26. 5. 1961., 5 .

Jeruzalemska Biblija, Zagreb 1994.

Dušan MARINKOVIĆ, Iz tijesna vremena, Zagreb 2001.

Krešimir NEMEC, Vladan Desnica, Zagreb 1988.

Petit Robert, Paris 1993.

Predrag PROTIĆ, „Zabeleške uz čitanje jedne drame. Marginalija uz 'Ljestve Jakovljeve' Vladana Desnice", Zadarska revija, 17/1968., br. 1, 67.

Dušan RAPO, Književni rad Vladana Desnice, disertacija, Filozofski fakultet, Zagreb 1984.

Drago ROKSANDIĆ, „Vladan Desnica i Desničini susreti: razmišljanja povodom 25. obljetnice Desničinih susreta”, Dijalog s povodom 5. Vladan Desnica i Desničini susreti: pogled unatrag, pogled unaprijed, (ur. Drago Roksandić i Ivana Cvijović Javorina), Zagreb 2013., 89.-114.

Jean-Paul SARTRE, L'existentialisme est un humanisme, Paris 1946.

Milivoj SOLAR, „Tehnika uvođenja eseja u roman Proljeća Ivana Galeba”, Zbornik radova o Vladanu Desnici, (ur. Dušan Rapo), Zagreb 2004.

The Otherness of God, (ur. Orrin F. Summerell), Charlottesville - London 1998.

Zbornik radova o Vladanu Desnici, (ur. Dušan Rapo), Zagreb 2004.

Agata ZIELINSKI, Levinas - la responsabilité est sans pourquoi, Paris 2004.

Slavoj ŽIŽEK, O vjerovanju, Zagreb 2005. 